Sebastian SKOLIK

Elżbieta ROBAK

\title{
1.1. FACTORS SHAPING COOPERATION IN FORMAL ORGANIZATIONS AND INFORMAL SOCIAL MOVEMENTS
}

\begin{abstract}
Summary
Interaction of people in the work environment is a complex social process and depends on many different factors. Both, managing modern organizations, as well as the social environment, researchers are trying to answer questions about the basis for the people and the factors determining its effectiveness. As it is more and more common to take initiatives based not on formal structures, but on an informal network of communities, particularly in the area of Internet, thoughts about the problem becomes a matter of comparison and to determine the differences between working in organizations and often forming ad hoc communities aimed at the production of goods or for mutual provision of services. Coordination and control of human behaviour in cooperating groups is associated not only with the system of authority, formal and informal norms of group, but also with confidence. Cooperation requires trust and may contribute to the development of trust.

To determine the conditions of cooperation in two different environments authors decided to adopt a number of research methods - interview survey in the case of formal organizations and participant observation and content analysis for informal social movement, generating a number of different communities' activities. The authors described research results based on their own questionnaire studies conducted among the workers of formal organizations and results of an analysis of the contents and results of an observation conducted since 10 years on the project society of Wikimedia.
\end{abstract}

Keywords: cooperation, confidence, human interactions, workplace

\section{Introduction}

Taking into account formal organization, it may be assumed that reaching the goals by the organization is dependent on the efficiency of the task forces (Robak and Sierpińska, 2009, p. 210). Nevertheless, together with the appearance of the phenomenon of global sharing information and knowledge via the Internet, informal communities of action began to develop (Bendkowski, 2009). Within this informal movement, the shaping networks of cooperation do not require to be managed by managers, which is important in case of formal organizations. In order to have the task force in the companies working effectively, the manager should be communicative, open to various problems, treat co-workers as partners and support initiatives presented by the members of the team. (Robak and Sierpińska, 2009, p. 211). In case of the projects created by the members of informal social movements' openness, partnership 
and cooperation appear almost autonomously and automatically, nevertheless it is possible to cooperate between such type of movements and formalized organizations (Tapscott and Williams, 2008). Such kind of cooperation autonomy was defined especially for social movements creating project by the Internet and the meaning of the term ,autonomy” seems to be insufficient for describing the sources of cooperation. It is still an open question, to what extent such way of cooperation could be transferred into the ground of formal organizations. Maybe such interpersonal relationships in these two work environments, different in terms of the technical means of communication, are intransferable, in relation to each other.

The issue that arouse interest among the researchers was comparing of the two work environments according to the various forms of cooperation. Appearance of the publications presenting the effects of the operations of online communities effected in the attempt to use the forms of cooperation used in the organization models. If the goods manufactured by the professional workers of an organization may be compared to the goods manufactured in the online communities, the key issue would be a question concerning the fact why the efficiency of the paid workers may be lowered that the results of the volunteers' actions. There also may be noticed that for the members of the online communities freedom and spontaneity in action is less import ant than professionalism and quality. In case of freedom, it means resigning from imposing of the quality framework for the manufactured goods and imposing of the way of action on the workers.

\section{Identification of the sources of cooperation within the work environment}

In case of cooperation among the members of online communities, there are some profits presumed coming from mutual improving of the products. The authors presume that the causative factor of the involvement is also satisfaction from cooperation. The prerequisite for each type of cooperation is the possibility of effective communication between the people participating in the certain project. With reference to the environment of the Internet it is highly debatable, that media, including mainly Internet, in case of the information society, contribute to manipulation of the recipients, which decreases their reliability (Golka 2008, pp. 129-132). Because of the fact, that information society at the same time becomes consumer society, the flow of information that everybody can use, unifies ,the participants around the same values and tasks" (Golka 2008, p. 133).

Communicating therefore is not synonymous with communication. As shown based on the experimental research, people not knowing each other in person, but communicating via the Internet have poorer ability to assess emotions of the partner in this interaction (Wallace 2003, pp. 26-27). The research was focused on the initial interactions, and it may be assumed that personal acquaintance does not require direct face-to-face contact. The phenomenon of presumption has to be taken into account, which becomes an alternative towards generated by the industrial society division into producers and consumers. Presumption occurs while the difference between producer and consumer disappears, because the last ones share the produced goods with the others. (Gulik, 2013). It may be concluded that where the goods are produced together, 
cooperation may be forced, regardless the environment. Hofmokl presents a list of conditions, providing coordination of activities towards common-pool resources:

- designated boundaries for the individuals using the resources;

- adaptation of the rules of using the resources to local conditions and needs;

- possibility of modifying (reinterpretation) of the rules by most of the members belonging to a given community;

- respecting by the superior (authorities) the rules created by the members of society;

- possibility to monitor the action within the system created by the society members;

- access to inexpensive methods of solving conflicts (Hofmokl, 2009, pp. 40-41).

Existence of the common resources, which become both goals and values of given societies, taking into account the use of given methods, may be defined as the next source of cooperation. It is worth mentioning that the rules and the ways of its sanctioning should be, by the members of society, divided fostering building of trust among each others. Some of the authors claim that informal rules, are often more favourable for cooperation, than formally established norms. (Kulesza, 2010, pp. 52-58). It seems that in such cases cooperation is possible only if it works together with sharing the mutual assets. In case of enterprises, usually (not taking into account enterprises in a form of cooperatives) the members of the teams are employers, therefore participating in the produced goods by obtaining them in the same way as other consumers do.

Consumer is only a passive participant on the market of the cultural goods (both tangible and intangible). This kind of culture L. Lessig describes as Read-Only Culture, with opposing Read/Write Culture, in which the individuals actively participate in a process of creating the text. (Lessig, 2009). Not only the access to common assets, but also participation in the process of its creation, may strengthen cooperation. Commonly produced goods are values, towards which the individuals may have the sense of common goal and sense of cooperation. Towards such already produced values they constitute various types of social movements, e. g. functioning in order to promote access to public assets, or creating Project such as Wikipedia, which millions of users participate. At the same time they become historically the greatest projects, in which people can cooperate in the global scale (Jemielniak, 2013, p. 16). In case of the enterprises, which most often work in the local scale, the equivalent of cooperation within global movement may be informal structure, in which significant elements are: „customary behaviour code, informal leader, system of values setting informal goal of a given group, informal sanctions influencing behaviour of the members of given group according to the intentions of this group (Robak and Bylok, 2009 , p. 60). It is an open question, to what extent the way of functioning of an informal leader, who in case of small venture is the owner, is similar to spontaneously (bottom-up) appointed leaders within the global networks of cooperation. What is connected to that, whether the system of sanctions and the ways of solving problems, which is being created spontaneously, may be adopted to organization with the already existing, formalized structure? The structure of formalized movement is closer to the 
market on which goods are being exchanged, and the participants of this exchange do not create plans for realization of an enterprise (Raymond, 1999).

The last source of cooperation may be a mixture of various factors, which lead to emergent qualities. Such situation is described by D. Tapscott and A.D. Williams (2008), defined as wikinomics. According to them, in the modern business the following values should be rejected: focus on the client, protecting of intellectual properties against being accessed by other subjects, focus on controls conducted by the managing staff, and local action with global thinking. At the same time there should be assumed the four rules of wikinomics: openness understood as sparing data concerning the company; partnership meaning resignation from hierarchical management style; sparing assets- in this case it means e.g. resignation from the full protection of intellectual assets and acting to global scale (Tapscott and Williams, 2008, pp. 40-55). In order to make the global cooperation possible, all of the above-mentioned rules have to be fulfilled. It may be assumed, that the main, initiating source of cooperation is here mainly the global scale and mass scale of engaging into various types of the enterprise.

\section{Methodological perspective of the research}

In order to compare the problem of cooperation within two various work environments- in the area of informal social movement and in the area of formal organization - it would be difficult to define methodology, that would be in both of this cases equally successful. The conclusion is that formal organizations are rather closed forms, also with reference to the researchers, who could conduct a participant observation. On the other hand social movement seems to be such an object, that may be examined more effectively by means of this technique, because of the openness towards ,the strangers”. It may be also assumed that conducting the research with the use of separate methods should allow to collect data possible for comparative analysis. Because of the fact that one of the most active social movements cooperation- oriented while creating goods are volunteers focused around the projects of Wikimedia Foundation, environment worth examining may be one of the local project of this foundation. In some specific language versions Wikipedia, belonging to the group of such projects, there work several to several thousands of volunteers. Because almost all action and interactions between the users of these projects are taken explicitly, the data collected as a part of a long-term participant observation, as well as analysis of the websites created by the users. The shares on their own websites (homepages) often present information concerning themselves and their attitude to the enterprise, in which they take part in. Additionally, on the dedicated websites - talkpages - the interactions while solving common problems may be observed. It seems to be more organizationally difficult to have the questionnaire study conducted. Frequent using the technique of questionnaire study causes an effect of saturation and the users take part in the next surveys less enthusiastically. (Kozinets, 2012, pp. 114-115). In order to illustrate specific situations connected with cooperation, there may be conducted the analysis of particular case studies. 
On the opposite, in case of formal organizations, conducting the research is more difficult, especially with the use of the method of participant observation. Because of that it is more effective to use the method of questionnaire study (Gruszczyński, 2001, p. 7). Apart from the presence of an observer among the employees, it cannot be hidden, what is possible in the Internet Project. In this case it is also a problem to define the research sample. People taking part in the wikimedia movement do not originate from any specific environments, and joining the Project for them is often accidental. With reference to the fact that among the active members of the Wikimedia community, the greatest group is composed of the students, it was presumed that conducting of the survey study among the working students will allow to compare both of these communities. Taking into account the above mentioned difficulties, the authors have decided to use:

- their own questionnaire studies conducted among the workers of formal organizations,

- results of an analysis of the contents and results of an observation conducted since 10 years on the project society of Wikimedia.

In order to have the possibility to state the difference concerning cooperation of people within these two work environments, the following research questions were stated:

- Is there any difference in the type of cooperation with reference to their sources?

- Is the atmosphere of trust a necessary condition of cooperation, or maybe it is an effect of cooperation, if many network initiatives is based on trust, how about people, who did not have any contact so far?

- Which conditions have to be met in order to make cooperation leading to emotional, subjective perceiving everything as a source of pleasure and fun, which seems to be characteristic for the Internet action communities?

- Do the values, with which the organization personnel is identified, help to create the atmosphere of cooperation?

- What determined trust to the rules within various work environments?

\section{Research results}

The survey tests concerning cooperation within an environment of formal organization were conducted in April and May 2015. For the research analysis there were accepted 204 questionnaires filled up by the respondents. All of the examined people work in the enterprises employing 5 or more people, located mainly in the area of Silesian province, Lodz province and other neighbouring provinces. Among the respondents there were 132 women and 102 men. The respondents were mainly young people, at the age from 20 to 29 years, declaring mainly secondary or higher education. 113 of the respondents have been working in the current workplace for 2 years or shorter, in case of 56 people their seniority in the workplace was between 3 and 10 years; 23 people worked from 11 to 20 years; 11 people were employed in the same workplace over 20 years. Most of the respondents were employed in the small and medium- sized enterprises, only one for four respondents was employed in the large-sized enterprises. 31 people worked in the sector of industry, 12 in the building and construction sector, 
8 in transport, 96 in the sector of trade and services, 14 in the institutions connected with education and healthcare, 28 in administration and 17 in other sectors.

In the analysed movement of Wikimedia, regulation of the forms of cooperation is referred to the internalized set of rules. It was assumed that also in the formal organizations one of the factors influencing the cooperation of co-workers is internalization of the organizational values. Respondents were asked to indicate among the nine values the ones that are considered to be respected in their workplaces and values internalized by them. The analyses of the research materials show that the greatest discrepancies between the workers' expectations and the values that may be realized within the organizations were connected with autonomy in decision - making and participation of the employees in making changes. For $41 \%$ of the respondents decision making was treated as their value, not the value of an organization, similarly for the $29 \%$ of the respondents - participation in introducing the changes was their value rather than the value of an organization. It proves that the need for subjectivity is relatively often not met in formal work environments. The problem of subjectivity also appears in the researched environment of Wikimedia. The way of functioning of the Wikimedia environment is based on freedom in participation of the users. Nevertheless, by the institutionalization of the action procedures, for the news the procedure of introducing changes in the cooperation rules is limited.

As shown by the survey analysis, the employees marked more often that the values important to them are not considered as significant by the organizations they work for, and it is more common than the reversed situation. Only several respondents marked the organization values, that were not their own. Table 1 presents detailed comparison of the values internalized by the employees and values respected in their work places.

Table 1: Compatibility of the values internalized by the employees with the values considered as important in their work place

\begin{tabular}{|l|c|c|c|c|}
\hline \multirow{2}{*}{ Values } & \multicolumn{2}{|c|}{ Internalized by the worker } & \multicolumn{2}{c|}{$\begin{array}{c}\text { Not internalized by the } \\
\text { worker }\end{array}$} \\
\cline { 2 - 5 } & $\begin{array}{c}\text { Respected in } \\
\text { the company } \\
(1-1)\end{array}$ & $\begin{array}{c}\text { Not respected } \\
\text { in the } \\
\text { company (0-1) }\end{array}$ & $\begin{array}{c}\text { Respected in } \\
\text { the company } \\
(1-0)\end{array}$ & $\begin{array}{c}\text { Not respected } \\
\text { in the } \\
\text { company (0-0) }\end{array}$ \\
\hline Quality of the work results & 184 & 9 & 4 & 1 \\
\hline Punctuality & 183 & 10 & 11 & 3 \\
\hline $\begin{array}{l}\text { Self-reliance in decision- } \\
\text { making }\end{array}$ & 109 & 58 & 8 & 22 \\
\hline $\begin{array}{l}\text { Good relationship with the } \\
\text { co-workers }\end{array}$ & 155 & 39 & 2 & 2 \\
\hline Cooperation in the teams & 143 & 33 & 9 & 14 \\
\hline $\begin{array}{l}\text { Mutual support in a } \\
\text { workplace }\end{array}$ & 143 & 42 & 5 & 8 \\
\hline Mutual trust & 151 & 42 & 3 & 2 \\
\hline Loyalty towards the superior & 170 & 14 & 10 & 3 \\
\hline $\begin{array}{l}\text { Workers' participation in } \\
\text { introducing changes }\end{array}$ & 93 & 81 & 9 & 14 \\
\hline
\end{tabular}

Source: own calculations 
In order to mark the conformity level towards the important values in the work environment, the researchers invented the following scale:

- a very high conformity level meaning that all of the presented values were important for both, employees and the company;

- high conformity level meaning that 7 or 8 among the presented values were important for both, employees and the company;

- medium conformity level meaning that 5 or 6 of the presented values were important for both employees and company;

- low conformity level meaning that 3 or 4 of the presented values were important for both, the employee and the company;;

- very low conformity level meaning, that only 1 or 2 of the presented values were important for both, the employee and the company;

In order to identify whether the conformity level influences the cooperation, the respondents' answers concerning their cooperation were compared to the above mentioned indicators of the conformity level. The results are presented in Figure 1.

\section{Figure 1: Evaluation of cooperation of the workers vs. the conformity level towards the values $N=194$}

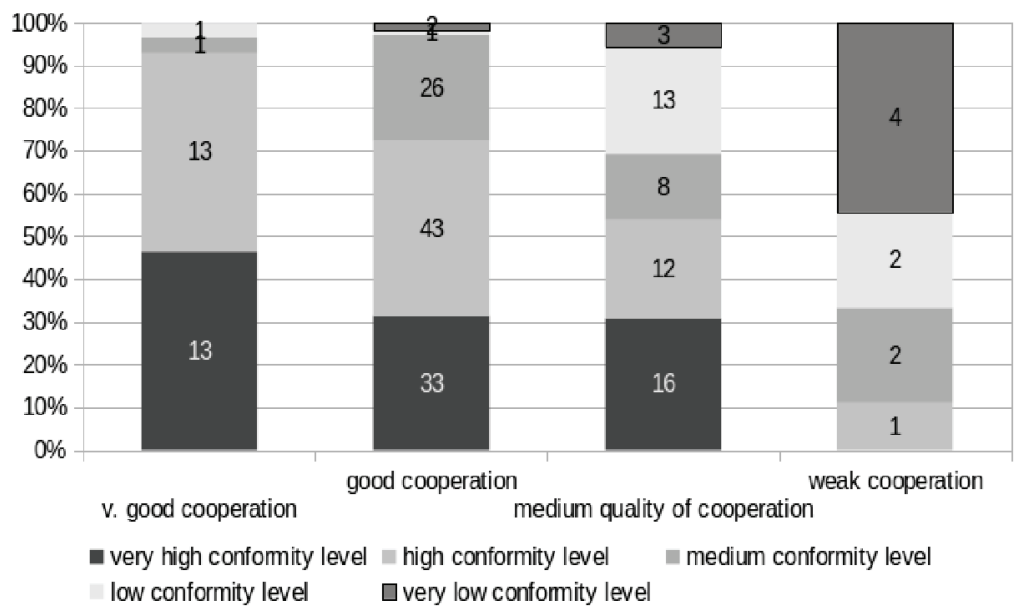

Source: own calculations

On the basis of the data presented it may be noticed that the more internalized are the organization values by the workers, the higher is the evaluation of their cooperation in a workplace.

The next analysed source of cooperation was trust towards the co-workers. As the research results show (illustrated in Figure 2) high evaluation of the cooperation is connected with the positive experiences in the relations of support from the coworkers, which is a significant factor creating trust. It should be highlighted that according to the respondents, trust built on the basis of the positive relationships, to the greater extent lead to cooperation, than unconditional trust. It means that in the work environment the positive experience of support is necessary in order to have the people trust each other and cooperate. It is a significant difference with reference to the environment of Wikimedia, in which unconditional trust towards people joining the 
movement is taken for granted. Nevertheless, trust is verified during the process of cooperation, by evaluation of the user contribution to the process of creation of common goods.

Figure 2: Evaluation of cooperation of the workers vs. the sense of trust towards coworkers $N=203$

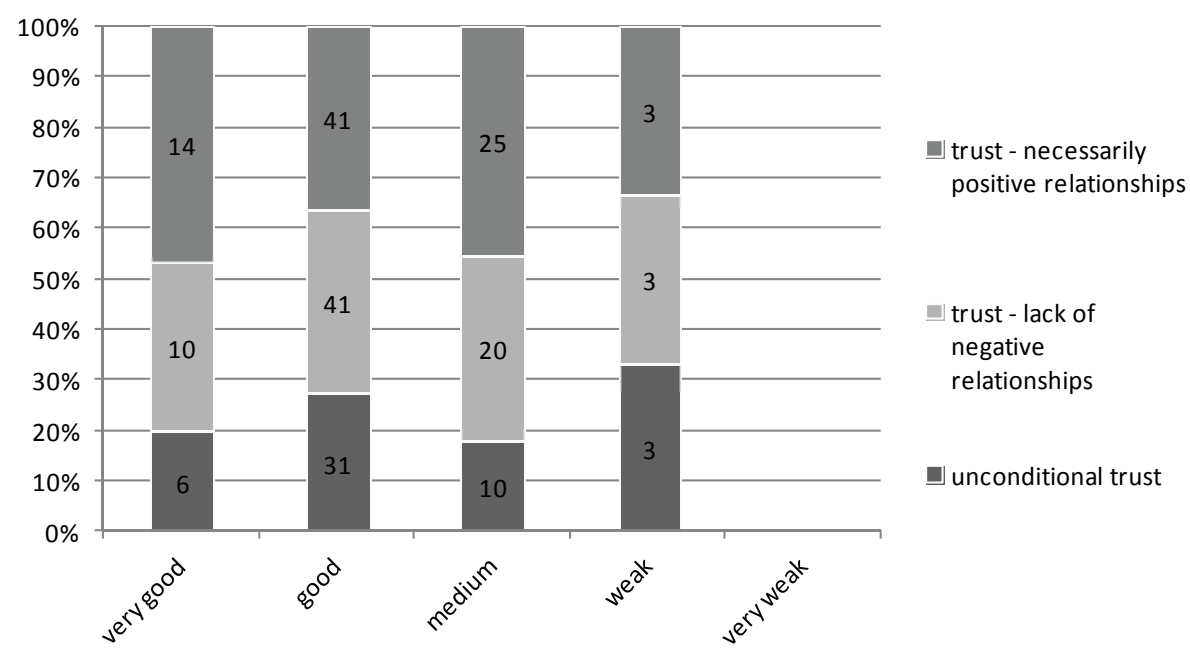

Source: own calculations

Figure 3: Trust as a value vs. sense of mutual support

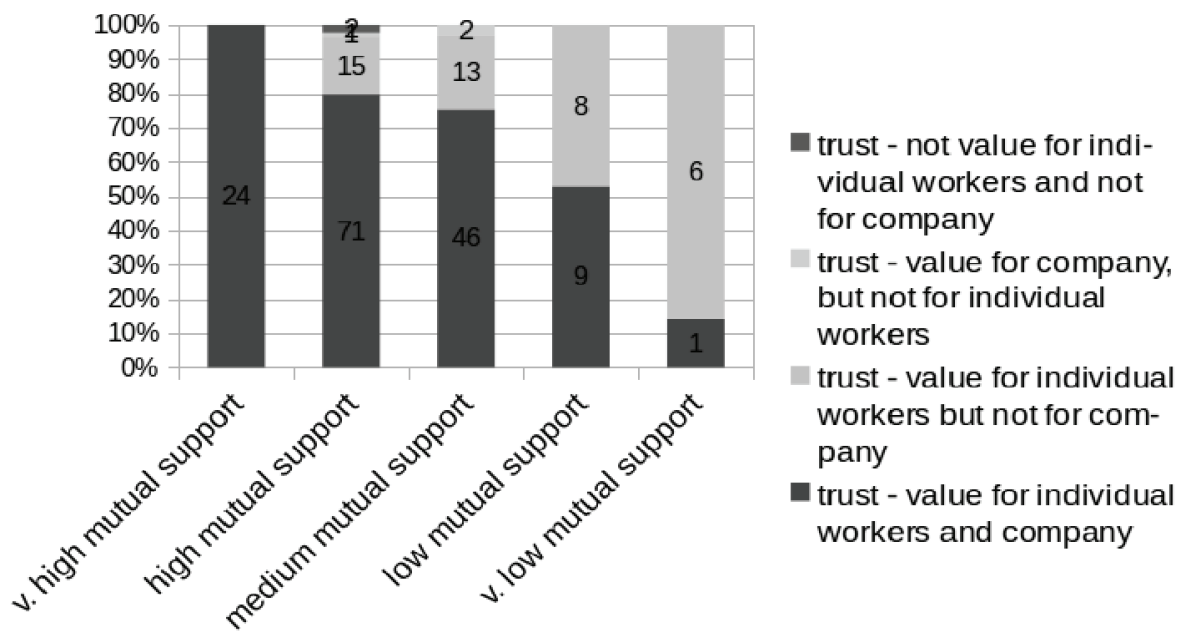

Source: own calculations

Trust is the value for both, individual workers and the company, in which they are employed, if there dominates the sense of mutual support and "sticking together". In the situation of lack of support, trust still remains the value of the employee, but he does not perceive trust as the value of the company (Figure 3).

In the environment of Wikimedia there was not examined the relation between the sense of cooperation with other workers towards the conditions of trust. Nevertheless, it was observed that together with appearance of conflicts, e.g. concerning the contents 
published in Wikipedia, next frequent prosecutions concerning acting against the rules. If the escalation of the conflict takes place, it often leads to the situation in which some of the project participants leave the society with comments describing the community as untrustworthy. Especially, it concerns the conflicts with the members possessing the right to sanction the behaviours of others (e.g. removing them from the project). In the year 2011 there were some research conducted concerning the sense of trust towards the administrators of Polish Wikipedia. Analysing the questions asked to the candidate administrators it was noticed that the users ask more questions concerning the solutions of particular problems. It may prove the need for detailed checking of a given candidate in a situation of dealing with particular problems and finding solutions for them. At the same time, previous unconditional trust (in the initial years of existing of the project there were some cases of awarding powers "in absentia") now becomes strongly conditioned. Change in the frequency of a given type of questions is presented in Fig. 4.

Analysing cooperation of people in the work environment, there should not be skipped the question connected with communication. Therefore, in both, formal organizations and environment of Wikimedia the researchers analysed the notion of communication formalization, referring to the awareness of the relationships with other people within their work environment and sense of openness in a process of communication with others.

Figure 4: Increase in the number of questions concerning resolving of particular problems (being an evidence of the developing lack of trust) towards the general questions

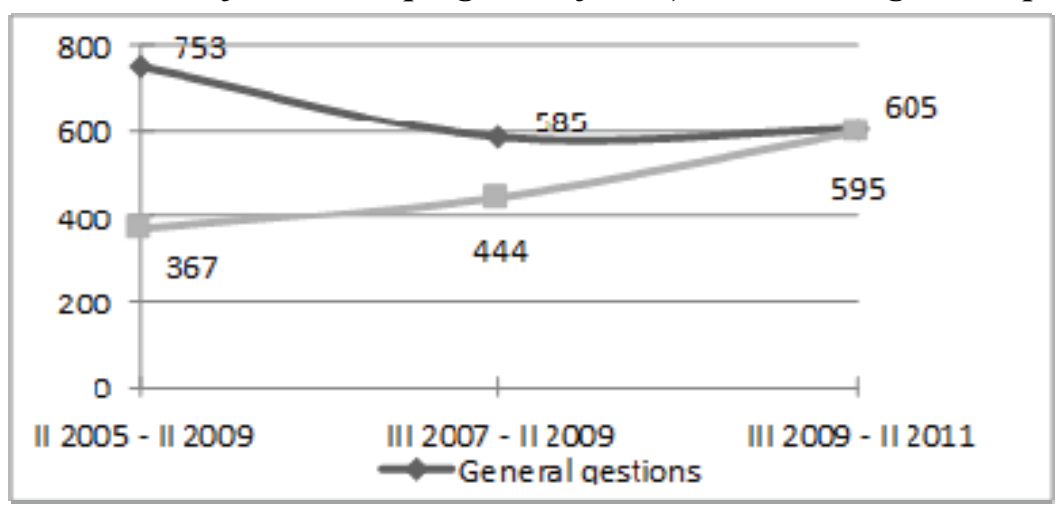

Source: own calculations published in (Jemielniak and Skolik, 2011)

In case of the questionnaire studies conducted among the workers employed in the formal organizations, what marked communicational openness was the responses of the respondents marking to what extent it is easy to express their own opinions. Whereas the indicator of the degree of informality of communication were respondents answers determining to what extent formal communication dominates over the "friendly" form. It appeared that both of the variables are rather independent, which is illustrated in Figure 5. In case of the analysed social movement it may be noticed that together with limiting of the openness in communication by the users, there takes place a switch to the formal approach in relationships. In the utterances there appear both polite forms, as well as ironic servility, which is in opposition to informal character of 
Skolik, S. - Robak, E.

the project and the accepted netiquette. Maybe adoption of the certain rules concerning communication forms fosters increase, or decrease in the communicational openness.

Figure 5: The degree of communication formalization within an organization vs. the sense of communicative openness of the employee

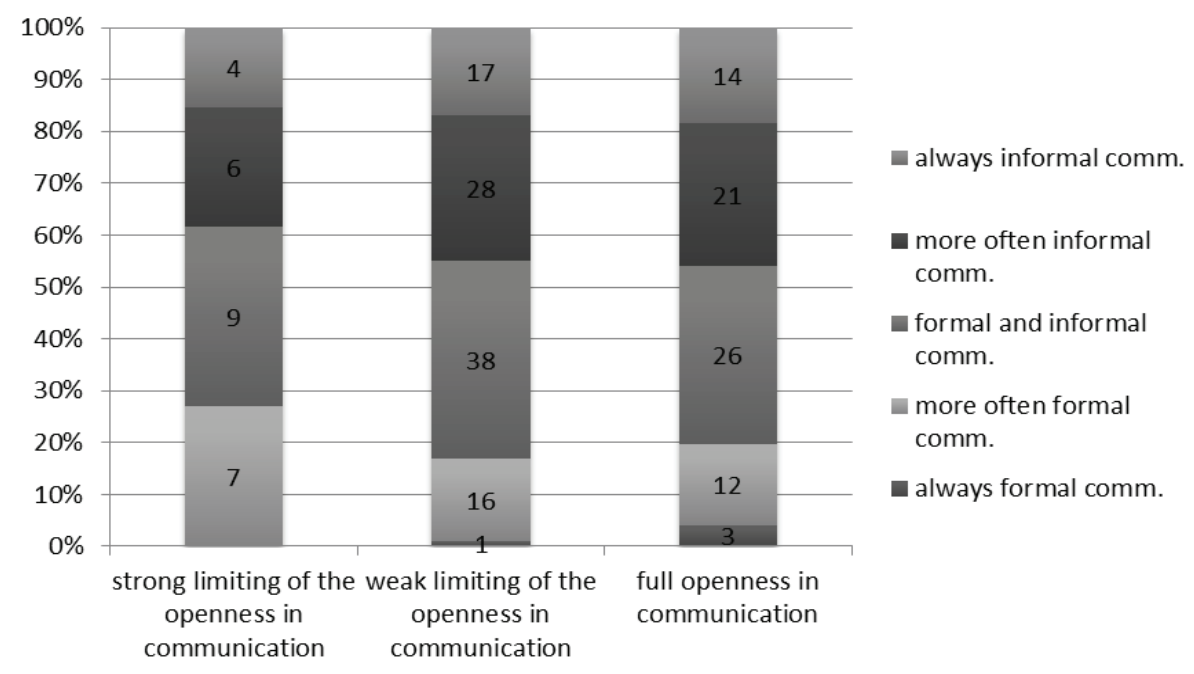

Source: own calculations

The research shows that informal communication fosters shaping of the informal relationships in a workplace. Whereas the level of communication formalization does not influence building of formal relationships (Figure 6 and 7).

Figure 6: The level of communication formalization within an organization vs. informal relationships between the workers

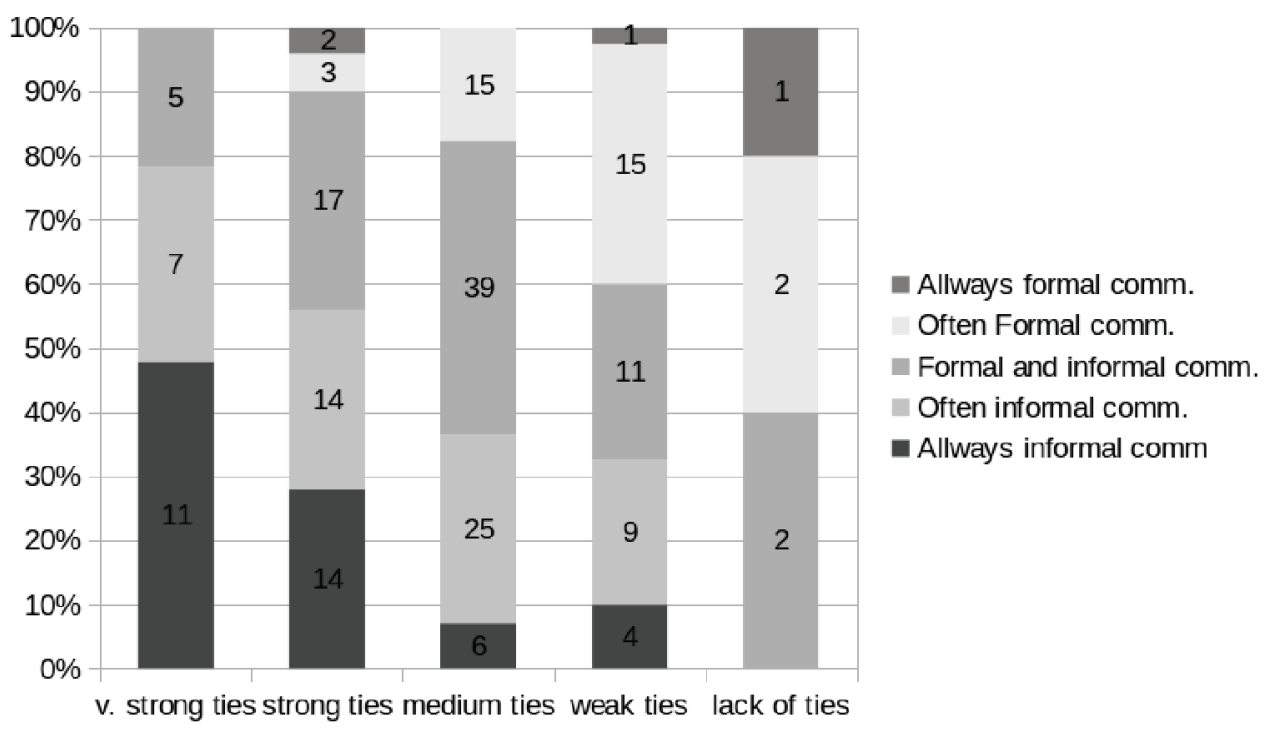

Source: own calculations 
Figure 7: The level of communication formalization within an organization vs. formal relationships between the workers $\mathrm{N}=204$

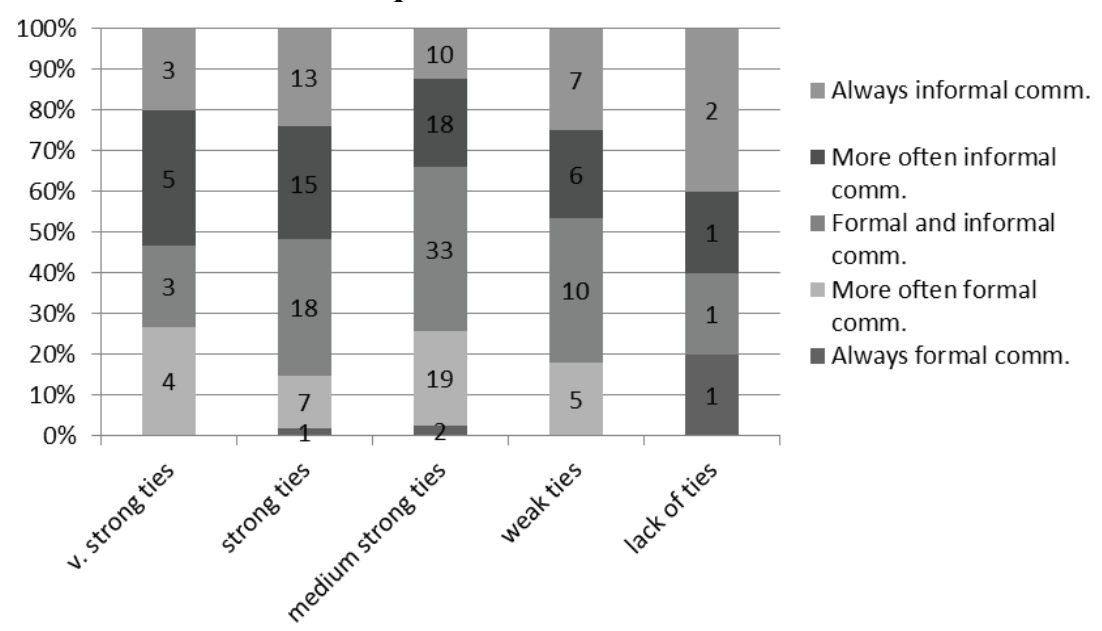

Source: own calculations

The last problem analysed in terms of the issues connected with cooperation within work environment is the attempt to determine the socio- demographic variables, that could influence cooperation.

In the analysed social movement, the elder people to the smaller extent were positively set towards informal forms of communication. The problem may be connected with the difficulties in accepting the rule that the person should resign from the polite forms (or formal forms) regardless the age, or social position outside the virtual world. It turns out that it is not only the issue of the environment itself, but also among the organization members, the younger people take formal way of communication more often, which is illustrated in Figure 8.

Figure 8: The level of formality of communication within an organization vs. the age of the respondents $N=157$

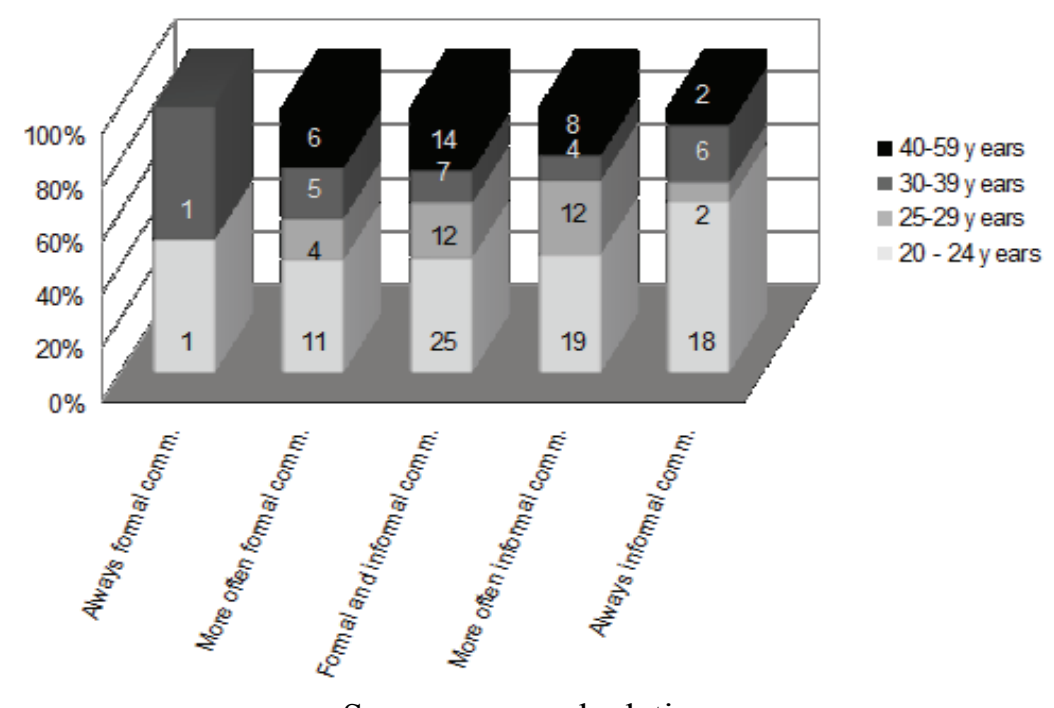

Source: own calculations 
Because, as presented above, the conditional trust replaces unconditional trust in the environment of Wikimedia, the dependency between the work seniority and perceiving the workplace as fostering the atmosphere of fun was also analysed. Figure 9 presents the results of the comparison of both these variables. As it may be noticed, the longer is seniority, the less often the job is connected with the atmosphere of fun. It may be explained as an effect of routinisation of the activities.

The similar phenomenon may be observed in the initiatives by Wikimedia. The longer they last, the less often they are described as pleasurable, besides less people are involved in creating the new ones. The more the co-created project is treated as professional, the smaller is the acquiescence on the spontaneous action and deviations from the accepted standards. Increasing number of standards additionally makes the structure stiffer and lowers the spontaneity in action.

Figure 9: The frequency of feeling by the respondents the atmosphere of fun in the workplace with respect to their seniority $N=203$

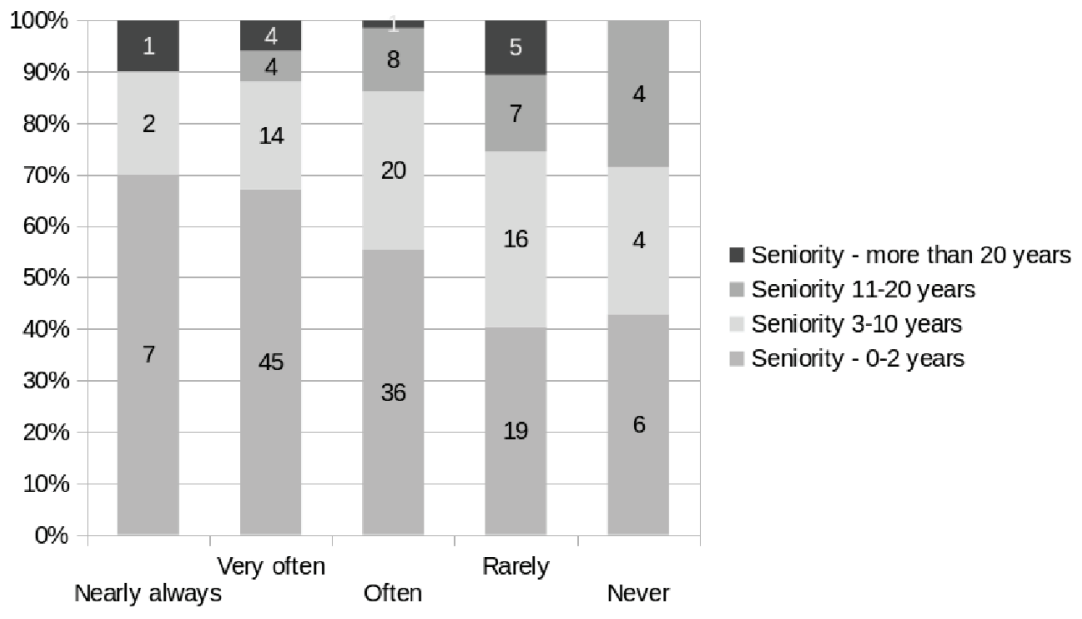

Source: own calculations

An example may be an increase in the number of standards marking "encyclopaedism" (minimal conditions that have to be met in order to have the term located in the encyclopedia) for the terms included in Wikipedia, that was presented in the Table 2.

Table 2: Increase in the number of the new criteria for encyclopaedism in the years 2006-2011

\begin{tabular}{|c|c|c|}
\hline Years & $\begin{array}{c}\text { Elaborated criteria for } \\
\text { „encyclopaedism” }\end{array}$ & $\begin{array}{c}\text { Created suggestions of } \\
\text { „encyclopaedism” }\end{array}$ \\
\hline $2006-2007$ & 4 & 17 \\
\hline $2008-2009$ & 8 & 9 \\
\hline $2010-2011$ & 3 & 7 \\
\hline
\end{tabular}

Source: own calculations 


\section{Research conclusions, limitation and perspectives}

With relation to the issue of cooperation of the examined workers of the formal organizations, the following conclusions were formulated:

- the more internalized are the values of the organizations by the employees, the higher is the evaluation of cooperation in a work environment;

- the need for subjectivity is relatively often not met in the formal work environment;

- high quality of cooperation is connected with positive experience of relations of support from the co-workers, building trust;

- trust built on the basis of the positive relationships to the greater extent leads to cooperation, than to unconditional trust;

- informal communication fosters development of interpersonal relationships in a workplace, formalized communication does not influence shaping of the factual relationships.

Limitations of presented studies are mainly related to methodological difficulties arising from the diversity of the two analysed work environments and a small attempt of conducted survey.

Presented issues certainly do not cover a broad spectrum of issues and problems concerning cooperation. However, considerably more research is needed to gain additional insight into the problem. Despite the fact that many researchers undertook search for an answer to the question which factors impact on effective cooperation of people, this is still an open area for exploration. Dynamically changing work environment constitute an incessant challenge to explore issues of cooperation. Comparison the functioning of formal organizations and informal social movements is one of many possible analyses of cooperation in the context of the modern information society.

\section{References}

1. Bendkowski, J. (2009): Społeczne aspekty tworzenia systemów zarządzania wiedzą opartych na wirtualnych wspólnotach działań. In: Komputerowo zintegrowane zarządzanie, (eds.) Knosala, R. Oficyn0a Wydawnicza Polskiego Towarzystwa Zarządzania Produkcją, Opole, pp. 88-95.

2. Gulik, E. (2013): Konsument, prosument, produser transformacja podmiotu wymiany rynkowej $\mathrm{W}$ społeczeństwie sieci, „Kultura $i$ Historia”, $\mathrm{nr} 24$, URL http://www.kulturaihistoria.umcs.lublin.pl/archives/5040 (accessed 29 April 2015).

3. Golka, M. (2008): Bariery w komunikowaniu i społeczeństwo (dez)informacyjne, Wydawnictwo Naukowe PWN, Warszawa, 282 p.

4. Gruszczyński, L. (2001): Kwestionariusze w socjologii. Budowa narzędzi surveyowych, Wydawnictwo Uniwersytetu Śląskiego, Katowice, 282 p.

5. Hofmokl, J. (2009): Internet jako nowe dobro wspólne, Wydawnictwa Akademickie i Profesjonalne, Warszawa, $162 \mathrm{p}$.

6. Kozinets, R.V. (2012): Netnografia Badania etnograficzne online, PWN, Warszawa, 295 p. 
7. Kulesza, J. (2010): Ius internet. Między prawem a etyką, Wydawnictwa Akademickie i Profesjonalne, Warszawa, $248 \mathrm{p}$.

8. Jemielniak, D. (2013): Życie wirtualnych dzikich, Poltext, Warszawa, 176 p.

9. Lessig, L. (2009): Remiks, Wydawnictwa Akademickie i Profesjonalne, Warszawa, 300 p.

10. Raymond, E. (1999): The cathedral and the bazaar, „Knowledge, Technology \& Policy”, 12(3), pp. 23-49.

11. Robak, E.; Sierpińska, M. (2009): Trening kompetencji społecznych jako forma doskonalenia umiejętności menedżera w zakresie kształtowania efektywnych zespołów. In: Psychologiczne i socjologiczne aspekty zarządzania zasobami ludzkimi, (eds.) Bylok, F., Harciarek, M. Wydawnictwo Politechniki Częstochowskiej, Częstochowa, p. 334.

12. Robak, E.; Bylok, F. (2009): Grupy w organizacji i ich wpływ na zachowania ludzi. In: Zachowania ludzi w organizacji. Wybrane zagadnienia, (eds.) Bylok, F., Robak, E. Wydawnictwo Politechniki Częstochowskiej, Częstochowa, p. 253.

13. Skolik, S. and Jemielniak, D. (2011): Otwartość i zaufanie w organizacji opartej na wolnych licencjach na przykładzie Wikipedii. In: W kierunku zrównoważonej gospodarki opartej na wiedzy w Polsce, (eds.) Sochaczewski, P. Wydawnictwo WSZE w Białymstoku, Białystok, pp. 92-104.

14. Skolik, S. (2012): Rola użytkowników końcowych w prosumenckim modelu tworzenia oprogramowania MediaWiki. In: Wykorzystanie wybranych technologii komunikacyjnych w zarządzaniu wartością organizacji, (eds.) Kiełtyka, L. Wydawnictwo Politechniki Częstochowskiej, Częstochowa, pp. 227-241.

15. Skolik, S. (2014): Przemiany w systemach wartości w środowisku nieprofesjonalnych pracowników wiedzy. Studium przypadku polskojęzycznej Wikipedii. In: Nowe kierunki w zarządzaniu współczesnymi organizacjami, (eds.) Skiba, Ł. Czarnecka, A. Wydawnictwo Wydziału Zarządzania Politechniki Częstochowskiej, Częstochowa, pp. 167-177.

16. Tapscott, D.; Williams, A.D. (2008): Wikinomia. O globalnej współpracy, która zmienia wszystko, Wydawnictwa Akademickie i Profesjonalne, Warszawa, 416 p.

17. Wallace, P. (2003): Psychologia Internetu, Rebis, Poznań, 355 p. 